\title{
Effect of Human Relation Skills Training Program for Head Nurses on Staff Nurses Organizational Commitment
}

\author{
Nevine Hassan Abd El-aal, Lecturer \\ Nursing Administration, Faculty of Nursing, Damanhour University
}

\begin{abstract}
Human relation skills may play a significant role in the development of employees, and improvement of organizational commitment and performance. Objective: To determine the effect of human relation skills training program for head nurses on staff nurses organizational commitment. Subjects: All head nurses $(n=18)$, staff nurses $(n=69)$ working at El-Mabara and El-Zahraa hospitals in El Beheria Governorate. Tools: Two tools were used in this study namely: human relation skills scale for head nurse's and organizational commitment scale for staff nurses. Results: revealed that the total mean score of head nurses for human relation skills was $126.3 \pm 12.5$ which significantly improved to $143.1 \pm 5.9$ after two months of implementing the program. Also, about half of the staff nurses (55.1\%) had high organizational commitment before implementing the program while $85.5 \%$ after two months of implementing the program reveals high organizational commitment. In addition, the highest factor affecting human relations among head nurses was leadership skills influencing others. Conclusion: There is an effect of human relation skills training program for head nurses and on their staff nurses organizational Commitment which is proved statistically. Recommendations: In-service training program should be provided periodically for both head nurses and staff nurses as well as all other healthcare providers about human relation skills to improve their knowledge in the previously mentioned two hospitals.
\end{abstract}

Key words: human relations, organizational commitment.

\section{Introduction}

Human relation is defined as an area of management practice which is concerned with the integration of people into a work situation in a way that motivate them to work productively, cooperatively and with economic psychological and social satisfaction $^{(1)}$.

Nurses are one of the largest groups in healthcare work force and constantly interact with patients, their relatives, colleagues as well as other members of the multi-disciplinary health care team inside and outside the healthcare organization ${ }^{(2)}$.

Good nursing human relations develop when two healthcare personnel interact with each other to achieve the primary goal of maximum patients satisfaction and health promotion irrespective of their field of work $^{(3)}$.
Graham et al. (2009) stated that human relations are considered as fuel of behaviors. The three levels of behavior are: the individual, the group, and the organization. The collective behavior of those three levels influence the organizational performance. Performance is the extent to which expectations or objectives are met ${ }^{(4)}$.

Reobert and Lussier (2013) divided human relations in organizations into four main aspects. The first is intrapersonal skills: behavior, and performance. These lie within individuals. This part includes characteristics such as personality, attitude, values, self concept, integrity, and self management abilities such as time management. In addition, this part answers the question; why are human relation skills so important? ${ }^{(5)}$. The second aspect include 
interpersonal skills: They represent the nature of interaction that occurs between two or more individuals who fulfill each other's needs in some way. This part answers the question; How does interpersonal communication affect behavior, human relations and performance $?^{(6)}$. The third aspect include leaderships skills; influencing others. Actually, the art of influence is a key leadership component, and uses different tactics under different situations to change behaviors, opinions, attitudes, goals, needs and values. This part answers the question; how does leadership affect behavior, human relations and performance ${ }^{(7)}$. The last aspect is concerned with team, organizational behavior, and performance. This is the part which answers the question; how can teams affect behavior, human relations and performance $^{(8)}$. Hall and Barrett (2007) stated that a leader who has good human relation skills may wish to influence employees to increase their organizational commitment toward goals ${ }^{(7)}$. Good management evokes loyalty and organizational commitment ${ }^{(9)}$.

As a general rule, organizational commitment plays a very significant role in determining whether a member will stay with the organization and zealously work toward achieving organizational goals. ${ }^{(10)}$ It is defined as the strength of feeling responsibility of an employee towards helping to achieve the mission of the organization $^{(11)}$.

Meyer and Allen (2002) developed the three components model of commitment. The first is affection for the job (affective commitment) involves the employee's identification with the organization's goals and the values he/ she genuinely wants to implement. The second is the fear of loss (continuance commitment) where the employee feels the need to stay at the organization, and that the loss of the employment is much greater than the benefit that may be gained in a new role. The third is the sense of obligation to stay in the job (normative commitment) as the employee feels a sense of obligation to the organization and he/ she feels that they should stay with the organization, because it is the right thing to do ${ }^{(10,12)}$.

A study in USA (1999) explored effective human relations: as a guide to people at work. Through developing a manual, the study examined every major aspect of the relationships between people in work settings, including diversity quality and work teams ${ }^{(13)}$. Furthermore, Hyde et al. (2009) investigated human relations management expectations and healthcare in a qualitative study. They concluded that human relation practice and support, are linked to improved performance especially in relation to patient care and service innovations ${ }^{(14)}$.

In Egypt a study carried out by Madani (2000) showed the effect of education on the awareness of head nurses concerning their communication with the staff nurses. The study clarified that the effect of education on nurses' awareness in performing human relation with nursing personnel depends on work experience, age and the sex. In addition, prior to and following education, this awareness has differed greatly ${ }^{(15)}$.

One of the most significant developments in recent years has been the increased importance of human relation skills in almost every type of work setting. For many employers, human relation skills represent an important category of the transferable skills an employee is expected to bring to their job. Hence, effective human relation skills in organizations is a key for successful nurses' commitment to their organization as well as for managerial effectiveness. Failure in human relations among head nurses and staff nurses may lead to organizational problems and may lead to the need for a means to foster the effective human relation skills training program. In this response to these identified needs, the researcher developed human relation skills training program for head nurses. 


\section{Aim of the Study}

This study aims to determine the effect of human relation skills training program for head nurses on staff nurses organizational commitment.

\section{Research Hypothesis:}

There is an effect of human relation skills training program for head nurses on staff nurses organizational commitment?

\section{Materials and Method \\ Materials}

Design: This study is a quasi-experimental research design.

Setting: This study was conducted in all inpatient care units at El-Mabara and ElZahraa hospitals. These are private hospitals in El Behera governorate. They were selected as they are two of the biggest private hospitals and have the best reputation in the governorate. In addition, they encompass different medical specialties.

- El Mabara Hospital, consists of eleven inpatient care units namely; hemo-dialysis, ICU, High risk, Outpatient, operating room and first, second, third floor and an extended part for each one. There was 45 beds included.

- El Zahraa Hospital, consists of seven inpatient care units namely; Neonatal, ICU, operating room, emergency, and all internal units as: second, fifth and seventh floor. There was 45 beds included.

Subjects: The subjects of the study included all head nurses $(\mathrm{N}=18)$, and staff nurses $(\mathrm{N}=69)$ in the above hospitals who were available in all inpatient care units during the time of data collection. They were distributed as follows:

- El Mabara Hospital eleven head nurses and forty staff nurses.

- El Zahraa Hospital seven head nurses and twenty nine staff nurses.

$\underline{\text { Tools: }}$ Two tools were used in this study:
Tool I: The human relations skills scale

It was developed by the researcher based on International Business Machines $(2008)^{(16)}$, and Lussier (2009) ${ }^{(17)}$ and a review of related literature ${ }^{(5,18-19)}$.

It is conducted to assess the head nurses' skills that contribute to effective human relations as well as to determine areas of strength and those areas that need improvement. It consists of 50 sub-items under four main items namely: intrapersonal skills: behavior, and performance (11 sub-items), interpersonal skills: (13 sub-items), leadership skills: influencing others (17 sub-items), team, organizational behavior, and performance (9 subitems).

Responses were measured on a fourpoint likert scale ranging from 3 (always do this) to 0 (never do this).

\section{Tool II: Organizational commitment scale}

It was developed by the researcher based on Brown (2003), Meyer and Allen (2007) and Dorgham (2012) $)^{(20-22)}$ to determine the extent to which the staff nurses of an organization see themselves as belonging to the organization and feel attached to it. It consists of 15 statements. Responses were measured on a 5-point likert scale ranging from "5" strongly agree to "1" strongly disagree. Negative reversed statements were reverse coded before the analysis.

Attached to this questionnaire were demographic data of head nurses and staff nurses such as age, gender, marital status, and their educational qualifications. Also, the name of hospital, type of units, years of experience in nursing and years of experience in nursing units were included.

\section{Method}

1. An official permission was obtained from El-Mabara and El-Zahraa Hospital to collect the necessary data.

2. The human relation skills and organizational commitment tools were translated by the researcher into Arabic language and submitted to 
five experts in the field of the study for content validity. Accordingly, the necessary modifications were done.

3. The reliability of the two tools were tested by measuring the internal consistency of items using Cronbach's alpha. Human relations tool items proved to be in item I (0.779), item II (0.809), item III (0.815) and item IV (0.884). In addition, organizational commitment tool proved to be reliable (0.852).

4. A pilot study was carried out on $(10 \%)$ of the subjects $(n=2$ head nurses and $\mathrm{n}=7$ staff nurses) from Dar El-Salam Hospital in Damanhour Governorate. It was utilized to ensure the clarity of the tools, identify obstacles and problems that may be encountered during data collection, and to estimate the time needed to complete the questionnaires.

5. Ethical consideration; the purpose of the research was explained to all head nurses and staff nurses. Confidentiality and privacy were assured and their right to withdrawn from the research at any time was explained.

6. Data were collected in three phases:

i. Exploratory phase: Data were collected starting from $24 / 5 / 2014$ to $7 / 6 / 2014$ in the all shifts by the researcher from all head nurses to assess their level of skills for their human relations before implementing the program. Data were collected also from staff nurses to assess their level of their organizational commitment, before implementing the program in the previously mentioned two hospitals.

\section{ii. Planning phase:}

a. Development of the program: Based on the results of the exploratory phase and on the review of related literature. The human relation skills training program as well as the teaching sessions and time schedule were developed.

b. Implementing human relation skills training program: A human relation skills training program was developed based on a thorough review of related literature ${ }^{(16,17,20,23-26)}$ to improve human relations and organizational commitment as well as was implemented for head nurses at the previously two hospitals based on lack of their human relations knowledge and their desire to attend the training program.

7. A permission was obtained from the hospital manager. Furthermore, the head nurses were notified formally about human relation skills program a week before its implementation.

The teaching strategies and audio visual materials were utilized in the human relation skills training program are modified lectures, group - discussion, role play and brain storming. Moreover handouts was distributed.

- The program was conducted in one week period from $21 / 6$ to $26 / 6 / 2014$. The head nurses $(\mathrm{N}=18)$ were divided into three groups, each group comprised six members. Each group received two sessions for two days, each session comprised of two hours.

iii. Evaluation of human relation skills training program phase: Evaluation of the training program was carried out after two months of its implementation. Data were collected after two months of the program implementation from the head nurses $(\mathrm{N}=18)$ and staff nurses $(\mathrm{N}=69)$ using the previously mentioned tools to determine the effect of human relation skills training program for head nurses on staff nurses organizational commitment. It took a period from $27 / 8 / 2014$ to $10 / 9 / 2014$.

\section{Ethical Considerations:}

- A written consent of the participating subjects was obtained.

- Assuring confidentiality of data and anonymity of subjects. 


\section{Statistical Analysis}

After the data were collected, they were revised, coded and fed to statistical software SPSS IBM version 20. The given graphs were constructed using Microsoft excel software. Statistical analysis was done using two tailed tests and alpha error of 0.05 . The following statistical tests were applied:

- Descriptive statistics in the form of frequencies and percentages were used to describe the categorical data while mean and standard deviations with median and range for numeric data following normal distribution.

- Score \% change for commitment and human relations scales was calculated by subtracting the baseline score of the post intervention multiplied by 100 over the baseline score. To test for change of scale levels before and after intervention, Mc-Nemar test was utilized for categories while the paired t-test was applied for numeric scores.

- To test for the association between subjects characteristics and their change at scores, Kruskal Wallis test was used if more than two groups; otherwise, Mann-Whitney test was used to identify the relative importance of each item. Factor analysis was done to identify the factors loading for each one which is the correlation with the construct of the scale.

\section{Results}

Table (1) represents the demographic and characteristics experience of the study subjects. It was observed that the highest percentage of head nurses age (44.4\%) were in the age group 40 years and more and three quarters of staff nurses $(76.8 \%)$ those in the age group 20 to less than 30 years. While the lowest percentage $(22.3 \%)$ of the head nurses and $7.3 \%$ of staff nurses. Concerning the head nurses and staff nurses gender, the highest percentage of them were females $(83.3 \%, 84.1 \%$ respectively).
In relation to marital status, the highest percentage of head nurses $(66.7 \%)$ were married while $81.2 \%$ of staff nurses were single. Concerning educational qualifications, the highest percentage $(61.1 \%)$ of head nurses has secondary nursing school diploma, while $43.5 \%$ of staff nurses have bachelor of science degree in nursing. On the other hand, no one of head nurses have technical institute diploma (nursing section) while $14.5 \%$ of staff nurses have secondary nursing school diploma. As regards years of experience in nursing, the highest percentage $(44.4 \%)$ of head nurses have 21 years and more of experience in nursing, and that of staff nurses $(76.8 \%)$ have 6 to less than 11 years of experience in nursing compared to the lowest percentage of head nurses and staff nurses $(11.1 \%, 5.8 \%$ respectively) have 16 years to less than 21 years of experience in nursing. Also, more than half (55.6\%) of the head nurses work in medical - surgical units, while $43.5 \%$ of staff nurses work in the same unit. The lowest percentage of head nurses and staff nurse worked in the emergency unit $11.1 \%, 8.8 \%$ respectively. In relation to years of experience in nursing units, approximately one third of the head nurses $(33.3 \%)$ have 6 to less than 11 years of experience in nursing units. However, $78.3 \%$ of staff nurses have 1 to less than 6 years of experience in nursing units compared to the lowest percentage of head nurses $16.7 \%$ have 11 to less than 16 years of experience in nursing units and $2.9 \%$ of staff nurses have the same years of experience in nursing units.

Table (2) describes that the overall total mean score items of human relation skills of head nurses at the study phases were $(126.3 \pm 12.5)$ for pre-program which significantly improved to $143.1 \pm 5.9$ post two months of program implementation. In relation to intrapersonal skills behavior and performance and leadership skills: influencing others items, were (25.7 \pm 4.9 , $38.5 \pm 7.7$ respectively) pre program which significantly improved to $(31.2 \pm 1.8,48.9$ \pm 2.6 respectively) post two months of program implementation. On the other hand interpersonal skills, team, 
organizational behavior, and performance items pre program were $(36.6 \pm 3.1,25.5 \pm$ 2.2 respectively) which slightly improved to $(36.8 \pm 2.8,26.4 \pm 1.0$ respectively) post two months as well as proved to be insignificant $(\mathrm{p}=0.880,0.365$ respectively) in both two items.

Table (3) reveals that a significant difference was found in staff nurses organizational commitment at the study phases, about half of the staff nurses $(55.1 \%)$ had high organizational commitment before implementing the program which significantly improved to reach $85.5 \%$ after implementing the program (two months).

Table (4) portrays that the highest factors affecting human relations among head nurses (0.952) were leadership skills: influencing others "factor loading" followed by Intrapersonal skills: behavior, and performance, the third was interpersonal skills and the last one was team, organizational behavior, and performance $(0.915,0.872$ and 0.866 respectively).

Table (5) indicates that the highest median percent change $(17.1 \%)$ for head nurses human relations was recorded in age group 30 years to less than 40 years compared to $6.5 \%$ of them were 40 years and more and the differences were to be insignificant. As regards gender and educational qualifications the differences were found to be significant in both of them and the highest median percent change was in male and having others (diploma of specialty) $(29.1 \%, 14.2 \%$ respectively) compared to $7.2 \%$ in female and no one have technical institute diploma (nursing section). Concerning years of experience in nursing, type of units and years of experience in nursing units were not significant, and the highest median percent change in years of experience in nursing $(16.7 \%)$ who have 11 years to less than 21 years of experience in nursing compared to $6.5 \%$ were the lowest. Also, the highest median percent change of head nurses worked in O.R. unit (31.2\%) compared to $4.6 \%$ who were worked in I.C.U unit. Moreover, the highest median percent change (19.5\%) of head nurses have one to less than 6 years of experience in nursing unit compared to $5.8 \%$ of head nurses have 11 to less than 16 years of experience in nursing unit.

Table (6) illustrates, the differences were found to be statistically significant as regards staff nurse age and the highest median percent change $(31.0 \%)$ was in age group 30 years to less than 40 years compared to $11.1 \%$ was the lowest in the age group 40 years and more. Moreover, the differences were found to be statistically significant as regards gender of staff nurses, the highest median percent change $(29.6 \%)$ was observed in male. Concerning marital status the median percent change was approximately equal in both single and married staff nurses (20.6\% and $21.2 \%)$ respectively, and the differences proved to be insignificant. Furthermore, the educational qualifications of staff nurses the highest median percent change $(31.3 \%)$ belonged to those who graduated from technical nursing institute diploma while the lowest median percent change $(13.9 \%)$ who have secondary nursing school diploma and the differences were to be statistically insignificant. In relation to staff nurses years of experience in nursing the highest median percent change was $(32.3 \%)$ for those who have 16 to less than 21 years of experience in nursing compared to $11.1 \%$ was the lowest median percent change who have 21 and more years of experience in nursing and the difference proved to be insignificant. Regarding, type of units, the highest median percent change was recorded in the operating room $(26.1 \%)$ compared to $4.71 \%$ of staff nurses worked in I.C.U. and no statistically significant difference were found. Concerning, years of experience in nursing unit the difference were found to be statistically significant and the highest median percent change $(48.6 \%)$ of staff nurses with 11 years to less than 16 years of experience in nursing units compared to $11.1 \%$, was the lowest median percentage change of staff nurse with 16 and more years of experience in nursing units. 


\section{Discussion}

Effective human relations are the gate way towards achieving a healthy nursing practice environment, nurses' job satisfaction, organizational commitment and increasing the quality of care ${ }^{(27,28)}$.

This study shows significant improvement in the head nurses human relation skills after the program implementation particularly in both items; intrapersonal skills: behaviors and performance, as well as leadership skills: influencing others. This result may be attributed to the fact that knowledge and skills of human relations for head nurses may be present but needed more clarification and reinforcement. The program resulted on change, improvement, relationship effectiveness with staff nurses in the units and the organization. After program head nurses developed ability to work as a team and handle the stress effectively with staff nurses, they developed an appropriate leadership style and capabilities to change it, and to meet the needs of staff nurses. This result is consistent with Hameed et al., (2005) ${ }^{(29)}$ who reported a strong association between human relations before and after training $(\mathrm{p}<0.001)$. The same was supported by Dehaghani et al. (2010) ${ }^{(30)}$.

Likewise, Vesterinen et al. (2012) stated that the nurse manager is already considering their leadership style from the point of view of staff nurses, situation factors, and goals of the organization ${ }^{(31)}$. In this respect, Al-Kaladeh (2013) and Alloubani and Almatari (2014) assured that an improvement in interpersonal relations were accompanied by less conflict, higher levels of job satisfaction, stronger feelings of autonomy and increased staff nurses committed to the organization ${ }^{(32,33)}$. In this respect, Ahmed (2009) reported that, consequences of bad human relations between manager and their employee results in, lack of communication, lack of trust, stress, anger, conflict uncooperative behavior no team spirit and lack of commitment $^{(34)}$.

Moreover, two items as namely; interpersonal skills and team, organizational behavior and performance were found to be slightly improved but not significant differences. This may be attributed to the helping skills and knowledge acquired by the head nurses which may vary in their actual work practice this finding is consistent with college of nursing of Ontario (2014) ${ }^{(35)}$.

Also, this study proved the existent of a significant difference in staff nurses organizational commitment after program implementation for head nurses. This finding is consistent with McNees-smith (1995), zangaro (2001) and price (2009) who reported that an organization characterized by honest, open communication, trusting relationship and sense of belonging to the employee's, will increase the likelihood of retaining a morally committed employee ${ }^{(36-38)}$. In this respect, Bennett (2000) also mentioned barriers in organizations that reduce employee commitment include: personal relationship disruption, the threat to one's status $^{(39)}$.

In addition, this study revealed that leadership skills: influencing others item was the most effective one in head nurses human relations. This may be due to head nurses abilities as leaders to show confidence and respect, delegate the power to staff nurses in their work environment. This finding is expected and could be a result of the nature of head nurses work with staff nurses. The same was found by the two earlier studies in 2014 (Niagara Institute and Dianna) ${ }^{(40,41)}$.

Certain factors were found to affect head nurses human relation skills significantly such as: gender and educational qualifications as illustrated in this study. This finding is supported by Reece (2013). ${ }^{(42)}$ Conversely, Elsesser and Peplau (2009) reveled no significant difference were found between the ratings of male and female participant ${ }^{(43)}$.

Concerning the educational qualifications of head nurses and their human relation skills. the present study revealed that the highest median percent change was in others (diploma of specialty). In this regard White (2012) 
stated that nurse manager require highly educated nurse to provide driving force of change, sustained motivation, and practice the human relations in their clinical setting $^{(44)}$. While, Nayeri et al., (2012) reported that no significant difference was found for head nurses educational qualifications with their communication skills training program $(\mathrm{p}=0.1)^{(45)}$. Added to that, this study revealed that there was no significant difference in all others demographic characteristics of head nurses with their human relation skills.

Concerning staff nurses organizational commitment and their demographic characteristics significant differences were found the highest percent was in their age group ranging from 30 to 40 years; as nurses who have a less age were emotionally involved in the organization so they were committed. This result is consistent with Pala et al., (2008), ${ }^{(46)}$ Dorgham (2012) $)^{(22)}$ and Tsolaki (2013) ${ }^{(47)}$. In contrast, Ibrahem et al. $(2013)^{(48)}$ indicated that the staff nurses' age was not significant in relation to their organizational commitment.

Also, this study revealed that gender and organizational commitment had a significant difference. The highest percent was in males. This was expected as they need money for themselves and their families more than females. This finding is consistent with Pala et al., (2008), ${ }^{(46)}$ Mosadeghrad and Ferdosi $(2013)^{(49)}$. The contrast was found by Khalili and Asmawi $(2012)^{(50)}$ and Moneke and Umeh $(2014)^{(51)}$.

Regarding the marital status, educational qualifications, years of experience in nursing and the type of units did not show a significant difference in percent change. These results were supported by Siew et al., (2011), ${ }^{(52)}$ Dorgahm (2012), ${ }^{(22)}$ Khalili and Asmawi (2012), ${ }^{(50)}$ Moneke and Umeh (2014), ${ }^{(51)}$ Engeda, et al. $(2014)^{(53)}$. In contrast was found by Curran's (2001) ${ }^{(54)}$, Freund $(2005)^{(55)}$, Marayyan and Faoun (2008), ${ }^{(56)}$ Al-Hussami (2008) ${ }^{(57)}$.
Moreover, a significant difference was detected in staff nurses' organizational commitment and years of experience in nursing unit. The highest percent change was found in the staff nurses who had 11 to less than 16 years of experience in nursing unit. This could be due to their feeling of satisfaction and caring for their units and hence they are committed to the organization. This result was supported by Al-Aseeri, Ezzat (2007) ${ }^{(58)}$ and Dorgham $(2012)^{(22)}$ who reported that nurses who have organizational commitment are more emotionally attached and obligated to their organization. In contrast, Monek and Umeh (2014) concluded that no significant difference between years of employment with their organizational commitment ${ }^{(51)}$.

\section{Conclusion}

There is an effect of human relation skills training program for head nurses on staff nurses organizational commitment.

\section{Recommendations}

Based on the finding of the current study, the following recommendations have been generated:

1. Nursing education in different levels should put emphasis on the topics related to human relation skills in their programs.

2. In-service training program should be provided periodically for both head nurses and staff nurses as well as all other healthcare providers about human relations advantages to improve their skills in the previously motioned two hospitals.

\section{Recommendations for further study:}

1. Human relation skills training program for staff nurses and head nurses should be conducted at the different governmental hospital in El Beheira Governorate.

2. Study the factors of stimulating or hindering human relation skills for staff nurses in their nursing practice. 
Table (1): Demographic and characteristics experience of head nurses and staff nurses working in El-Mabara and El-Zahraa hospitals at El-Beheira governorate in 2014.

\begin{tabular}{|c|c|c|c|c|}
\hline \multirow{2}{*}{$\begin{array}{l}\text { Demographic characteristics of } \\
\text { head nurses and staff nurses }\end{array}$} & \multicolumn{2}{|c|}{ Head nurses (18) } & \multicolumn{2}{|c|}{ Staff nurses (69) } \\
\hline & No & $\%$ & No & $\%$ \\
\hline \multicolumn{5}{|l|}{ Age (in years) } \\
\hline - $20-$ & 6 & 33.3 & 53 & 76.8 \\
\hline - $30-$ & 4 & 22.3 & 11 & 15.9 \\
\hline - $40+$ & 8 & 44.4 & 5 & 7.3 \\
\hline \multicolumn{5}{|l|}{ Gender } \\
\hline - Male & 3 & 16.7 & 11 & 15.9 \\
\hline - Female & 15 & 83.3 & 58 & 84.1 \\
\hline \multicolumn{5}{|l|}{ Marital status } \\
\hline - Single & 6 & 33.3 & 56 & 81.2 \\
\hline - Married & 12 & 66.7 & 13 & 18.8 \\
\hline \multicolumn{5}{|l|}{ Educational qualifications } \\
\hline $\begin{array}{l}\text { - Secondary nursing school } \\
\text { diploma }\end{array}$ & 11 & 61.1 & 10 & 14.5 \\
\hline $\begin{array}{l}\text { Technical Institute diploma } \\
\text { (nursing section) }\end{array}$ & 0 & 0.0 & 11 & 15.9 \\
\hline $\begin{array}{l}\text { - Bachelor of science degree in } \\
\text { nursing }\end{array}$ & 3 & 16.7 & 30 & 43.5 \\
\hline - Others (diploma of specialty) & 4 & 22.2 & 18 & 26.1 \\
\hline \multicolumn{5}{|l|}{ Years of experience in nursing } \\
\hline - $6-$ & 5 & 27.8 & 53 & 76.8 \\
\hline - $11-$ & 3 & 16.7 & 7 & 10.2 \\
\hline - $16-$ & 2 & 11.1 & 4 & 5.8 \\
\hline - $21+$ & 8 & 44.4 & 5 & 7.2 \\
\hline \multicolumn{5}{|l|}{ Types of units } \\
\hline - Emergency & 2 & 11.1 & 6 & 8.8 \\
\hline - Neonatal & 2 & 11.1 & 11 & 15.9 \\
\hline - Medical - Surgical & 10 & 55.6 & 30 & 43.5 \\
\hline - Operation room & 2 & 11.1 & 14 & 20.3 \\
\hline - ICU & 2 & 11.1 & 8 & 11.5 \\
\hline \multicolumn{5}{|l|}{$\begin{array}{l}\text { Years of experience in nursing } \\
\text { units }\end{array}$} \\
\hline - $1-$ & 4 & 22.2 & 54 & 78.3 \\
\hline - $6-$ & 6 & 33.3 & 8 & 11.6 \\
\hline - $11-$ & 3 & 16.7 & 2 & 2.9 \\
\hline - $16+$ & 5 & 27.8 & 5 & 7.2 \\
\hline
\end{tabular}


Table (2): Average scores of human relations skill items for head nurses at the study phases $(n=18)$.

\begin{tabular}{||l|c|c|c|c|c||}
\hline \multirow{2}{*}{ Items of human relation skills } & \multicolumn{3}{|c||}{ Study Phases } & \multirow{2}{*}{ P } \\
\cline { 2 - 6 } & \multicolumn{2}{|c|}{ Pre } & \multicolumn{2}{|c||}{ Post two months } \\
\cline { 2 - 6 } & Range & $\begin{array}{c}\text { Mean } \pm \\
\text { SD }\end{array}$ & Range & $\begin{array}{c}\text { Mean } \pm \\
\text { SD }\end{array}$ & \\
\hline $\begin{array}{l}\text { 1. Intrapersonal skills: Behavior, } \\
\text { and performance }\end{array}$ & $18-33$ & $25.7 \pm 4.9$ & $27-33$ & $31.2 \pm 1.8$ & $0.001 *$ \\
\hline $\begin{array}{l}\text { 2. Interpersonal skills } \\
\text { others }\end{array}$ & $28-39$ & $36.6 \pm 3.1$ & $30-39$ & $36.8 \pm 2.8$ & 0.880 \\
\hline $\begin{array}{l}\text { Leadership skills: influencing } \\
\text { and performance }\end{array}$ & $25-48$ & $38.5 \pm 7.7$ & $41-51$ & $48.9 \pm 2.6$ & $0.001 *$ \\
\hline $\begin{array}{l}\text { Overall total items of human } \\
\text { relations skills }\end{array}$ & $109-147$ & $126.3 \pm 12.5$ & $125-150$ & $143.1 \pm 5.9$ & $0.001 *$ \\
\hline \hline
\end{tabular}


Table (3): Mean score percent for staff nurses organizational commitment at the study phases $(n=69)$.

\begin{tabular}{|c|c|c|c|c|c|}
\hline \multirow{3}{*}{ Levels of Organizational Commitment } & \multicolumn{4}{|c|}{ Study Phase } & \multirow{3}{*}{$\mathbf{P}$} \\
\hline & \multicolumn{2}{|c|}{ Pre-program } & \multicolumn{2}{|c|}{$\begin{array}{c}\text { Post-program (two } \\
\text { mths) }\end{array}$} & \\
\hline & No & $\%$ & No & $\%$ & \\
\hline Low $(0-21)$ & 3 & 4.3 & 1 & 1.5 & \multirow{3}{*}{$0.001 *$} \\
\hline Moderate (22-37) & 28 & 40.6 & 9 & 13.0 & \\
\hline High (38-60) & 38 & 55.1 & 59 & 85.5 & \\
\hline Range & \multicolumn{2}{|c|}{$20-56$} & \multicolumn{2}{|c|}{$24-60$} & \multirow{2}{*}{$0.002 *^{\#}$} \\
\hline Mean \pm SD & \multicolumn{2}{|c|}{$37.8 \pm 7.5$} & \multicolumn{2}{|c|}{$44.8 \pm 8.2$} & \\
\hline
\end{tabular}

P: Mc-Nemar test

\#: Paired t-test

$* \mathrm{P}<0.05$ (significant)

Mths $=$ months

Table (4): Factor Analysis (for weighting items) of human relations among head nurses.

\begin{tabular}{||l|c||}
\hline \multicolumn{2}{|c||}{ Component Matrix } \\
\hline \multicolumn{1}{|c||}{ Items of human relations } & Factor loading \\
\hline Intrapersonal skills: behavior, and performance & 0.915 \\
\hline Interpersonal skills & 0.872 \\
\hline Leadership skills: influencing others & 0.952 \\
\hline Team, organizational behavior, and performance & 0.866 \\
\hline \hline
\end{tabular}


Table (5): Demographic characteristics of head nurses and median percent change of their human relations at study phases $(n=18)$

\begin{tabular}{|c|c|c|c|c|}
\hline \multirow{2}{*}{$\begin{array}{c}\text { Demographic characteristics of head } \\
\text { nurses }\end{array}$} & \multicolumn{3}{|c|}{$\begin{array}{c}\text { Median percent change at study } \\
\text { phases }\end{array}$} & \multirow[t]{2}{*}{$\mathbf{P}$} \\
\hline & Minimum & Maximum & Median & \\
\hline \multicolumn{4}{|l|}{ Age (in years) } & \multirow[b]{2}{*}{0.236} \\
\hline $\begin{array}{ll} & 20- \\
\text {. } & 30- \\
\text {. } & 40+\end{array}$ & $\begin{array}{l}7.0 \\
2.2 \\
.00\end{array}$ & $\begin{array}{l}29.1 \\
31.3 \\
21.8\end{array}$ & $\begin{array}{l}15.4 \\
17.1 \\
6.5\end{array}$ & \\
\hline $\begin{aligned} \text { Gender } \\
\text { - } \\
\text { - } \text { Male } \\
\end{aligned}$ & $\begin{array}{l}28.3 \\
.00\end{array}$ & $\begin{array}{l}31.2 \\
31.3\end{array}$ & $\begin{array}{c}29.1 \\
7.2\end{array}$ & $0.021 *$ \\
\hline $\begin{array}{c}\text { Marital status } \\
\text { - Single } \\
\text { - } \quad \text { Married }\end{array}$ & $\begin{array}{l}7.0 \\
.00\end{array}$ & $\begin{array}{l}29.1 \\
31.3\end{array}$ & $\begin{array}{c}15.4 \\
6.5\end{array}$ & $0.223^{£}$ \\
\hline $\begin{array}{l}\text { Educational qualifications } \\
\text { - Secondary nursing school diploma } \\
\text { - Technical Institute diploma (nursing } \\
\text { - } \text { section) } \\
\text { - } \text { Others (diploma of specialty) } \\
\end{array}$ & $\begin{array}{l}.00 \\
.00 \\
2.2 \\
7.0 \\
\end{array}$ & $\begin{array}{l}31.2 \\
0.0 \\
29.1 \\
31.3\end{array}$ & $\begin{array}{c}10.6 \\
0.0 \\
9.9 \\
14.2 \\
\end{array}$ & $0.048 *$ \\
\hline 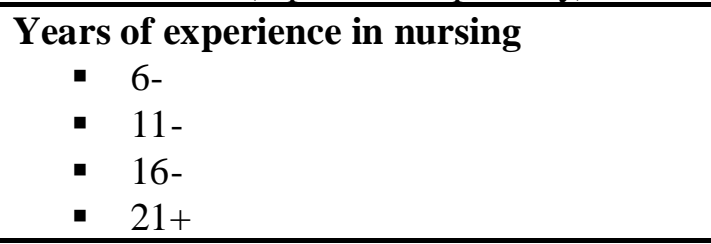 & $\begin{array}{l}7.0 \\
3.1 \\
2.2 \\
.00\end{array}$ & $\begin{array}{l}29.1 \\
31.3 \\
31.2 \\
21.8 \\
\end{array}$ & $\begin{array}{c}14.2 \\
16.7 \\
16.7 \\
6.5 \\
\end{array}$ & 0.404 \\
\hline $\begin{array}{l}\text { Types of units } \\
\text { - Emergency } \\
\text { - Neonatal } \\
\text { - Medical - Surgical } \\
\text { - Operation room } \\
\text { - ICU } \\
\end{array}$ & $\begin{array}{c}7.2 \\
3.1 \\
.00 \\
31.2 \\
2.2 \\
\end{array}$ & $\begin{array}{l}28.3 \\
16.7 \\
29.1 \\
31.3 \\
7.0\end{array}$ & $\begin{array}{c}17.8 \\
9.9 \\
11.9 \\
31.2 \\
4.6 \\
\end{array}$ & 0.139 \\
\hline 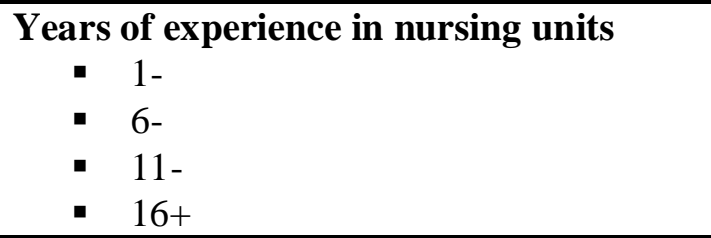 & $\begin{array}{l}7.0 \\
2.2 \\
1.4 \\
.00\end{array}$ & $\begin{array}{c}29.1 \\
31.3 \\
7.2 \\
21.8 \\
\end{array}$ & $\begin{array}{c}19.5 \\
15.4 \\
5.8 \\
13.2 \\
\end{array}$ & 0.331 \\
\hline
\end{tabular}

P:Kruskal-Wallis test

$£$ : Mann-Whitney test

$* \mathrm{P}<0.05$ (significant) 
Table (6): Demographic characteristics of staff nurses and median percent change of their organizational commitment at study phases.

\begin{tabular}{|c|c|c|c|c|}
\hline \multirow{2}{*}{$\begin{array}{c}\text { Demographic characteristics of staff } \\
\text { nurses }\end{array}$} & \multicolumn{3}{|c|}{$\begin{array}{c}\text { Median percent change at study } \\
\text { phases }\end{array}$} & \multirow[t]{2}{*}{$\mathbf{P}$} \\
\hline & Minimum & Maximum & Median & \\
\hline 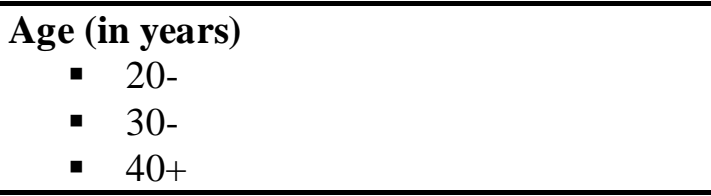 & $\begin{array}{c}-40.0 \\
10.9 \\
2.0 \\
\end{array}$ & $\begin{array}{c}119.2 \\
76.0 \\
61.8 \\
\end{array}$ & $\begin{array}{l}20.5 \\
31.0 \\
11.1 \\
\end{array}$ & $0.048 *$ \\
\hline $\begin{aligned} \text { Gender } \\
\text { - } \\
\text { - } \text { Male } \\
\end{aligned}$ & $\begin{array}{l}-40.0 \\
-37.0 \\
\end{array}$ & $\begin{array}{c}119.2 \\
91.3 \\
\end{array}$ & $\begin{array}{l}29.6 \\
18.2\end{array}$ & $0.050^{* f}$ \\
\hline $\begin{array}{c}\text { Marital status } \\
\text { - } \quad \text { Single } \\
\text { - } \quad \text { Married } \\
\end{array}$ & $\begin{array}{c}-40.0 \\
0.0\end{array}$ & $\begin{array}{c}119.2 \\
83.3\end{array}$ & $\begin{array}{l}20.6 \\
21.2\end{array}$ & $0.667^{\mathfrak{f}}$ \\
\hline $\begin{array}{l}\text { Educational qualifications } \\
\text { - Secondary nursing school diploma } \\
\text { - Technical Institute diploma (nursing } \\
\text { - } \text { section) } \\
\text { - } \text { Bachelor of science in nursing } \\
\end{array}$ & $\begin{array}{r}0.0 \\
-40.0 \\
-37.0 \\
-14.5 \\
\end{array}$ & $\begin{array}{l}119.2 \\
83.3 \\
65.4 \\
76.0 \\
\end{array}$ & $\begin{array}{l}13.9 \\
31.3 \\
20.9 \\
14.5 \\
\end{array}$ & 0.224 \\
\hline 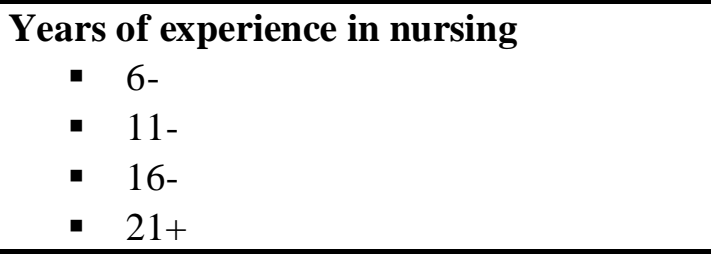 & $\begin{array}{c}-40.0 \\
10.9 \\
21.2 \\
2.0 \\
\end{array}$ & $\begin{array}{c}119.2 \\
76.0 \\
76.0 \\
61.8 \\
\end{array}$ & $\begin{array}{l}20.5 \\
25.0 \\
32.3 \\
11.1 \\
\end{array}$ & 0.184 \\
\hline $\begin{array}{l}\text { Type of units } \\
\text { - Emergency } \\
\text { - Neonatal } \\
\text { - } \text { Opedical - Surgical } \\
\text { - } \text { ICU }\end{array}$ & $\begin{array}{l}-40.00 \\
-22.92 \\
-9.09 \\
-36.96 \\
-23.68 \\
\end{array}$ & $\begin{array}{c}31.25 \\
43.33 \\
119.23 \\
91.30 \\
31.25 \\
\end{array}$ & $\begin{array}{c}21.32 \\
11.11 \\
22.86 \\
26.16 \\
4.71 \\
\end{array}$ & 0.060 \\
\hline $\begin{array}{l}\text { Years of experience in nursing unit } \\
\text {. } 1- \\
\text { - } 6- \\
\text { - } 11- \\
\text { - } 16+ \\
\end{array}$ & $\begin{array}{c}-40.0 \\
18.2 \\
21.2 \\
2.0 \\
\end{array}$ & $\begin{array}{l}119.2 \\
76.0 \\
76.0 \\
61.8 \\
\end{array}$ & $\begin{array}{l}19.3 \\
32.3 \\
48.6 \\
11.1 \\
\end{array}$ & $0.050 *$ \\
\hline
\end{tabular}

P:Kruskal-Wallis test

$£:$ Mann-Whitney test

$* \mathrm{P}<0.05$ (significant) 


\section{References}

1. Patidar J. Human relations. 2013; Available at: www.drjayeshpatidarblogspot.com. Retrieved on: June 10, 2014.

2. Miyamoto S. Nursing workforce development programs. Available at: http://www.aacn.nche.edu/governmentaffairs title.PDF. March 2014.

3. Petryni M. the importance of human relations in the work place. 2014. Available at:

http://smallbusiness, chron.com/importance -humanrelations-workplace.23061, html. Retrieved on: June 21, 2014.

4. Graham B. Ashworth G, Tunbridge J. 2009. A Geography of heritage: power culture and Economy. In. Corsane G. Davis P. Making sense of place multi-disciplinary perspectives. The Boydell Press 2014; 136140.

5. Reobert N, Lussier R. Human relations in organizations: applications and skills building. $7^{\text {th }}$ ed. McGraw-Hill/ Irwin; 2013; P. 22: 28 .

6. Cavazos M. What is the meaning of interpersonal relationship. 2013. Available at:

http://www.livestrong.com/article/229362.

Retrieved on: May 20, 2014.

7. Hall A, Barrett L. Influence the essence of leadership. 2007. University of Nebraska. Available at: http://www.ianrpubs.unl.edu/epublic/pages /publicationsD.JSP?publication. Retrieved on: June 23, 2014.

8. Morgeson F, Derue D, Karam E. Leadership in teams a functional approach to understanding leadership structures and processes. Journal of management 2010; 36 (1): 5-29.

9. Abdullah A, Hasan H. Relationships between the communication climate and organizational climate with commitment. The case of Kole $\mathrm{J}$ universiti TEK Nikal Kebangsaan Malaysia. 2005. Research Vote No. PJP/ 2003. PPA (6).

10. Grimsley S. Organizational commitment Definition, theory and types 2014; available at: http://education- portal.com/academylesson/organizationalcommitment. Html lesson. Retrieved on: June 30, 2014.

11. Scholl W. Organizational commitment 2008; university of Rhodeisland, Kingston. Available at: //www.uriedu./research/irc/Schollwebnote. Retrieved on: Jul 2, 2014.

12. Meyer J, Allen J. A three component conceptualization of organizational commitment. Human resource management April (3) 2002; 1-13.

13. Seta C, Paulus P, Baron R. Effective human relations: A guide to people at work: study guide. Paper back 30 Sep 1999.

14. Hyde P, Harris C, Boaden R, Cortvriend P. Human relations management expectations and healthcare a qualitative study. The Tavistock Institute, available at: http//hum.sagepub.com. 2009; 62(5): 701-725. Retrieved on: Jul 12, 2014

15. Madani GR. The effect of education on the awareness of head nurses on their communication with the staff nurses. The $7^{\text {th }}$ International Scientific Conference. University of Alexandria, Faculty of Nursing. November 2000.

16. International Business Machine (IBM). Applying human relations skills. 2008; McGraw-Hill companies. Available at: http://novellaqualive2.mhhe.com/sites/dl/free/P DF. Retrieved on: May 10, 2014

17. Lussier R. Human relations in organization. Applications and skills building. 9th ed. Irwin: McGraw-Hill; 2009. P. 462-83.

18. Reece B. Effective human relations interpersonal and organizational application. Cengage Learning company; 2011.

19. Hassan N. Staff nurses perception for job empowerment and organizational commitment at critical care unit. [Master Thesis], Faculty of Nursing, Alexandria University, Egypt, 1999.

20. Brown B. Employee's organizational commitment and their perception of supervisor's relations-oriented and task-oriented leadership behaviors. Published Doctoral Dissertation 2003; Faculty of Virginia Polytechnic Institute and State University. 
21. Mayer J, Allen M. Model of organizational commitment: measurement Issues. Southern University Collage of Bussines, Rouge, Baton 2007.

22. Dorgham SR. Relationship between organization work climate and staff nurses organizational commitment. Nature and Science 2012; 10(5): 80-92. Available at: http://www.sciencepub.net/nature.

Retrieved on: May 20, 2014.

23. Burns EL. Bradel BW. Health care management: organization design and behavior. 2011; Cengage brain company. Available at: http://mhbe.com Retrieved on: June 6, 2014.

24. McConneil CR. The healthcare supervisor on effective employee relations. Jones and Bartlett Learning Company; 1993.

25. Nearaja KP. Text book of communication and education Technology for Nurses. 2014. 574-590.

26. Douglas M. McGregor. The human side of enterprise (New York: McGraw-Hill). 1998. Available at: http://scholar.najah.edu/sites/default/fils.

Retrieved on: June 5, 2014.

27. Hess R, Norman L, Donelan K. Are nurses read for health care reform? A decade of survey research. Nursing Economics. 2012; 30(6): 31-8.

28. Siddiqui N. Investing in human relations for healthy nursing practice environment. American Journal of Nursing Research. 2011; 1(1): 10-19.

29. Hameed I, Keiwkarnka B, Sirisook V, Smitasiri S. Human relations in nurses, at the Pakistan Institute of Medical Sciences, Islamabad 2005; Journal of Public Health and Development 3 (1).

30. Dehaghani A, Hosseini H, Tavakol K, Bakhtiyari S. Relationship between communication manners of head nurses with job satisfaction of nurses under their supervision in educational hospitals of Isfahan University of Medical Sciences in 2006. Iran Journal nurses Midwifery Research 2010; 15(2): 49-53.

31. Vesterinen S, Suhonen A, Passivaara L. Nurse Manager's leader ship styles in finland. Nursing research and practice. 2012 ;(8)3;1-8.

32. Al-Kalaldeh T. A critical analysis of the effect of organizational culture and leadership style on employee's job satisfaction. Interdisciplinary Journal of Research in Business. 2013; 2(12): 15-26.

33. Alloubani A, Almatari M. Review: effects of leadership styles on quality of services in health care. European Scientific Journal 2014; 10(18): 118-130.

34. Ahmed T, Consequences of bad relations. April 2009 available at http://proactivepersonality,blogspot.com/2009/ 04/normal-o.false.

35. College of nurses of Ontario. Practice Guideline; RN and RN practice: the client, the nurse and environment . 2014;

36. McNeese-smith D. Job satisfaction, productivity and organizational commitment: the result of leadership. Journal of Nursing Administration 1995; 25(9): 17-26.

37. Zangaro GA. Organizational commitment: A conception analysis. Nursing Forum 2001; 36(2): 14.

38. Price S. Future directions for career choice research in nursing: a discussion paper. International Journal of Nursing studies. 2009; 46(2): 268-76.

39. Bennett SN. Work-related attitudes and job characteristics of expatriates. International Business Review 2000; 43(1): 21-31.

40. Niagara Institute. Inflecting skills for leadership 2014. The conference board of Canada. Available at: www.niagarainstitute.com Retrieved on: Nov 16, 2014.

41. Dianna S. The influence model using reciprocity to gain influence 2014. Available at: http//www.mindtool.com./pages/articles/influec ne model.htm. Retrieved on: Nov 25, 2014.

42. Reece B. Effective human relations; interpersonal and organizational applications. 2013; Business and Economics. Available at: http://books.google.ca/book? Retrieved on: Dec. 3/2014.

43. El Sesser K, Peplou L. Human relations SAGE publications 2009; 59(8):1077-1100. 
Available at: www.sagepublications.com Retrieved on: Dec. 10/2014.

44. White G. Comparison between heads of nursing and nursing administration students in the Sultanate of Oman regarding education for nurse administrators. 2012; Sultan Qaboos Uni Med J. 12(3): 315-22.

45. Nayeri N, Farahani A, Sharifi N, Hoseini M. Effect and staff development program on head nurses communication skills and job satisfaction. Nursing and Midwifery Studies 2012; 1(2): 62-6.

46. Pala F, Eker S, Eker M. The effect of demographic characteristics on organizational commitment and job satisfaction. Journal of Industrial Relations and Human Resources. 2008; 10(2): 13032860.

47. Tsolaki E, Tsironi M, Theofanis F, Tzavella F. Employee's commitment to the organization of a public district hospital: a case study: International Journal of Caring Sciences. 2013; 6(2): 258-67.

48. Ibrahem S, Elhoseny $\mathrm{T}$, Mahmoud R. Work place empowerment and organizational commitment among nurses working at the main University Hospital Alexandria, Egypt. Journal of the Egyptian Public Health Association 2013; 88(2): 906.

49. Mosadeghrad A, Ferdosi M. Leadership, job satisfaction and organizational commitment in health care sector. 2013. Journal of the Academy of Medical Science of Bosnia and Herzegovina; 25(2): 121-6.

50. Khalili A, Asmawi A. Appraising the impact of gender difference on organizational commitment. Empirical evidence from a private SME in Iran. 2012;
International Journal of Business and Management 2012; 7(5): 100-11.

51. Monek N, Umeh O. How organizational commitment of critical care nurses influence their overall job satisfaction. Journal of Nursing Education and Practice 2014; 4(1). Available at: www.sciedu.ca/jnep. Retrieved on: Sep 20, 2014.

52. Siew P, Chitpak D, Chontawan R. Factors predicting organizational commitment among nurses in state hospitals, Malaysia. The International Medical Journal Malaysia 2011; 10(2): 21-30.

53. Engeda E, Birhanu A, Alene K. Intent to stay in the nursing profession and associated factors among nursing working in Amhara Regional State Referral hospitals, Ethiopia. BMC Nurisng. 2014; 13: 24. Available at: http://www.biomedicalcentral.com/1472.6955/ 13/24. Retrieved on: Sep 23, 2014

54. Curran's, C. Stay, say, and serve. Nursing Economic 2001; 19(2): 41-2.

55. Freund A. Commitment and job satisfaction as predictors of turnover, intentions among welfare workers. Administration in Social Work 2005; 29(2): 5-21. Available at: http//doi.org/10.1300/. Retrieved on: Oct 18, 2014.

56. Marayyan M, Faoun I. Nurses career commitment and job performance: differences across hospital. Nursing Leadership 2008; 21(2): 101e-18e.

57. Al-Hussami M. A study of nurses' job satisfaction: the relationship to organizational commitment perceived organizational support, transactional leader, transformational leadership and level education. European Journal of Scientific Research 2008; 22: 286295. 